Sign Systems Studies 31.2, 2003

\title{
On the semantics of rhythm: Formal differences between the characters of Oresteia in tragedy
}

\author{
Maria-Kristiina Lotman \\ Dept. of Germanic and Romance Philology, University of Tartu \\ Ülikooli St. 17, Tartu, Estonia \\ e-mail: maria.lotman@mail.ee
}

\begin{abstract}
The paper analyses the formal features of the characters of Oresteia in Greek tragedy. The protagonists and the minor characters are compared, for which the rhythmical liveliness and variability of the personages' utterances, the length and number of utterances, and the number of dialogue verses in the metrical repertoire of the corresponding personage are taken into account. The analysis revealed that the data of Sophocles and Euripides are more close to each other both in the respect of general "liveliness" and the "liveliness" of characters' utterances. Certain differences in the metrics and rhythmics of the main and minor characters' verses become most obvious when we compare Electra's part with minor characters (e. g., in Electra's part there is always the biggest proportion of lyrical parts, more unstandard settlements, more verses with splits than any other character). The index of liveliness of Electra's part is almost the same in all the authors. Although the same tendencies in Orestes are more schematical, the metrics and rhythmics of his utterances are rather similar to those of Electra. Thus, in respect of the proportion of lyrical verses, he always comes second after Electra; he also has quite many split verses. The parts of minor characters are usually made up entirely of iambic trimesters, the rhythmical variety of their speeches is higher than average, but there are no splits in their parts (except for Aegisthus). However, there are characters which parts have unstandard rhythm, e.g., the pedagogue in Sophocles or Chrysothemis, who is a contrast to Electra by her nature as well as her rhythmics. The contrast with other minor characters is even bigger. Clytaemnestra's part is both rhythmically and metrically intermediate: in Aeschylus her utterances consist entirely of iambic trimeters, but in Sophocles and Euripides she pronounces also a couple of lyrical verses. There are also some splits in her verses which usually do not occur in minor persons.
\end{abstract}




\section{Introductory notes}

Literary theory has to share its object with other disciplines, above all, with literary criticism. Literary criticism considers the most diverse matters connected with literature to belong into its area of competence. In this sense, literary theory is always in worse position as compared to criticism - its field is more restricted and its statements are more reserved in all respects, sometimes they even seem to be redundant. If a scholar of literature attains results which have been earlier stated by a criticist, then the question arises: why did he even start this research? But if the results disagree with earlier declarations, then it is often explained in this manner that literary theory is engaged in castles in the air and not in reality. The difference lies not in more pithy and interesting statements, but in verifiability. The sophisticated statements of a criticist are the result of his intuition, taste, education, etc; in any case, they are individual and idiosyncratic, while the study of literature depends on materials, procedures, being therefore verifiable and independent of personal factors.

Boriss Jarcho was one of the most radical formalists, who fought for the verifiability of the literary analysis. For him every statement had to be proved in the way they are proved in every other empirical discipline and, thus, the best and the most transparent procedure was the statistical analysis of data. While many other Russian formalists were most of all interested in obtaining the most novel and interesting information, then for Jarcho the greatest challenge was to prove the wide-spread opinions and thus to transfer them from the sphere of opinions to the sphere of knowledge.

The study of the semantical and rhythmical structure of personages in drama was started by Boris Jarcho in his genre analysis that concentrated on the research of formal differences between tragedy and comedy. It is generally known that comedy differs from tragedy by its liveliness, abundance of action and commonness of thoughts, but also by distinct emotions of characters. Jarcho developed a method for determining reliable criteria to measure the above-named parameters. Thus, the basis for measuring liveliness in drama is the relationship between the number of utterances and the total amount of verses in a play, according to which the so-called index of liveliness is calculated; the density of action can be measured by the occurrences of personages acting in their own interests, but also by the frequency of physical action; the feelings of characters can be analysed on the 
basis of vocabulary and motives of action; the thoughts of characters become evident, e.g., from the content of maxims ${ }^{1}$. The material for Jarcho's research were Pierre Corneille's (1606-1684) tragedies and comedies. It turned out that the index of liveliness in Corneille's tragedies is remarkably lower than in his comedies $(0.15$ and 0.276 , respectively). As for the extent of action, then tragedy shows considerably less action than comedy, since higher personages often entrust their deeds to other persons. There are differences also in characters' emotions: the vocabulary associated with fear, sorrow, hate and courage prevails in tragedy, while in comedy feelings of love, joy and happiness are more frequent. The content of maxims is rather different as well - in tragedy social thematics, time, elevated feelings prevail, ${ }^{2}$ while in comedy we find more maxims about joy, lying, wealth, poverty, literature and arts (cf. also Gasparov 1969: 510; Lill 1988: 57-60). Such results are not novel and surprising at all, but they can be easily verified.

While the main purpose of Jarcho's research was to define the differences between genres through characters, then Marina Tarlinskaja, who partly proceeded from Jarcho, concentrated explicitly on character analysis, in particular, on rhythmic differences between Shakespeare's characters (Tarlinskaja 1987: 135-176). Tarlinskaja used two different strategies in segmenting the dramatic texts: (1) form-oriented segmentation or the analysis of utterances of different length; (2) character-oriented segmentation, where the parts of different characters were studied. Form analysis consisted of two parts: (a) character exchanges inside a line or the so-called split verses; (b) comparison of utterances of different length. Character analysis concentrated on (a) the differentiation of characters through rhythm; (b) the evolution of characters. Tarlinskaja (1987: 345) concludes that Shakespeare uses specific rhythmical variations of

\footnotetext{
1 Here it is important to conceive the limits of statistical method. Statistical method does not concentrate on single cases, but observes a case in a system within a prepostulated framework. Let us imagine, e.g., a situation where one character utters a maxim and another one repeats it ironically - the same maxim has here absolutely different meaning (the same can also be imagined in the lexical level, etc. Therefore, statistics is not a universal instrument to solve every problem, but qualifies only for certain aspects. As for the studies of semantics, it has an important role in increasing the verifiability and reducing the part of intuition.
}

2 For emotions in Greek tragedy see, e.g., Stanford 1983; Taplin 1983. 
iambic pentameter for different characters, whereby typologically similar characters display also similar rhythmical tendencies, being opposed to other characters, e.g., heroes to villains, the sophisticated to the impulsive, rulers to commoners, women to men, etc - it is typical that the iambic pentameters of the first numbers of the listed pairs are stricter, while those of the second members are looser. The regularities in the evolution of characters were manifested as well: as the character changed in the progression of drama, its rhythmical structure also changed, e.g., Othello, who at the beginning of the drama is a noble and harmonious person, deeply in love with Desdemona, and whose part is characterized by symmetrical and quite strict verses, becomes by the end of the drama jealous, chaotic, disharmonious and his verses become loose and asymmetrical as well. Accordingly, in Shakespeare more stringent and regular verse is associated with nobility, goodness, wisdom, peace and harmony, while looser forms are associated with lower features of character: villainy, stupidity, impulsiveness, inner discord and madness.

The present study examines the characters of three ancient tragedies based on the plot of Oresteia: the Libation Bearers of Aeschylus and Electra of Sophocles and Euripides. The versions of Oresteia with some modifications can be found already in the early literary tradition: among others already in Homer, but later also in Stesichorus and Pindar. The legend itself can be briefly summarized as follows: after returning from Troy, Agamemnon has been murdered by his wife Clytaemnestra and her lover Aegisthus, who then take possession of the throne in Argos. Orestes, Clytaemnestra's and Agamemnon's son, lives in exile under the trusteeship of Strophius. When he becomes adult, he secretly returns to Argos to avenge his father. There he meets his sister Electra, who helps him to execute his plan.

The plot of the tragedies is the same, but the three authors treat it rather differently: the same plot expresses different ideas and attitudes (e.g., the attitude towards oracle, matricide, etc), the same characters have utterly different natures and motives of action (cf. also Tucker 1901: xi-xii; Winnington-Ingram 1980: 217ff; Goldhill 1992: 93-96; Lill 1994: 232-234).

The purpose of the present study is to compare the formal features of characters, above all, their rhythmical structures, with main attention paid to the characters who are common to all three analysed tragedies, i.e. Electra, Orestes, Clytaemnestra and, of course, the chorus which, although slightly different in each tragedy, has schema- 
tically still the same function. Methodically, this analysis proceeds from the studies of Boris Jarcho and Marina Tarlinskaja: following the example of Jarcho, the indices of liveliness are calculated for each respective tragedy. In addition to that, also the indices of liveliness of the central characters are calculated in the present work. Following the example of Tarlinskaja, both the general form analysis and the character analysis are carried out.

\section{The general analysis}

\subsection{The relationship between the number of utterances and the total amount of verses in tragedy}

The index of liveliness in Libation Bearers of Aeschylus is 0.19, in Electra of Sophocles is 0.28 and Electra of Euripides 0.26. It appears that Sophocles and Euripides are in this respect closer to each other, while their difference from Aeschylus is almost as considerable as the difference between tragedies and comedies in Corneille's case. The Table 1 shows the indices of liveliness in different characters.

Table 1. The indices of liveliness in characters of Oresteia.

\begin{tabular}{|l|c|c|c|}
\hline Author & Aeschylus & Sophocles & Euripides \\
\hline Electra & 0.26 & 0.25 & 0.29 \\
\hline Orestes & 0.18 & 0.47 & 0.45 \\
\hline Clytaemnestra & 0.38 & 0.21 & 0.21 \\
\hline Chorus & 0.14 & 0.28 & 0.13 \\
\hline
\end{tabular}


In the case of Aeschylus it is notable that the roles of minor characters are more "lively". Thus, e.g, Clytaemnestra has a small, but at the same time an intense role. It is not so in the case of Sophocles and Euripides - rhythmically, the most lively part is that of Orestes, who is the second character in importance. The other characters of Sophocles and Euripides have also quite similar rates of liveliness. As the characters are actually quite different, then this aspect has no particular importance in the semantics of rhythm.

The average length of utterances is in Aeschylus 5.3, in Sophocles 3.6 and in Euripides 3.8; also according to these data Sophocles and Euripides resemble each other more. The most common length of utterances in all the three authors is 1 line: in Aeschylus 50.7\%, Sophocles $44.9 \%$, Euripides $66.3 \%$.

The minimum length of utterances in Aeschylus is 1 line, the maximum 66 lines. In Sophocles these data are respectively 0.25 (an utterance in a verse with a triple split) and 84, in Euripides 0.5 (an utterance in a verse with one split) and 85 .

The overwhelming majority of utterances in all the authors is formed by the short, i.e. 1-5 lines long utterances: $77.8 \%$ in Aeschylus, in Sophocles (0.25-5 lines) $88.5 \%$ and in Euripides (0.5-5 lines) $87 \%$. The proportion of medium utterances (i.e. 6-20 lines) is $15.8 \%$ in Aeschylus, in Sophocles 7.4\% and in Euripides 9.3\%. The long utterances occur as follows: in Aeschylus (21-66 lines) $6.4 \%$, in Sophocles (21-84 lines) 4.2\%, in Euripides (21-85 lines) 3.4\%.

The division of dialogue and lyrical parts is the following: $58 \%$ of the total amount of verses in Aeschylus are dialogue verses (the metre of which is iambic trimeter) and $42 \%$ lyrical verses, Sophocles has $75.5 \%$ dialogue verses and $24.5 \%$ lyrical verses, Euripides has $70.9 \%$ dialogue verses and $29.1 \%$ lyrical verses. Aeschylus has more lyrical parts as compared to other poets, since the part of chorus is considerably bigger than in Sophocles or Euripides (which, of course, is not related to the metrics of the given tragedy, but to the general tendencies in the development of tragedy ${ }^{3}$ ).

3 For the problems of dating see, e.g., Winnington-Ingram 1980: 231. 


\subsection{The proportion of split verses}

Aeschylus has no split verses, Euripides has some, in Sophocles we find them many. Table 2 illustrates the occurence of such lines which have one split.

Table 2. Lines with one split.

\begin{tabular}{|l|c|c|c|c|c|}
\hline Author & Electra & Orestes & Clytaemnestra & Aegisthus & Chorus \\
\hline Euripides & 4 & 4 & 0 & - & 0 \\
\hline Sophocles & 26 & 20 & 4 & 4 & 4 \\
\hline
\end{tabular}

In other words, Euripides has only four verses of such kind, all split between Electra and Orestes. Thereby, three of them stand in succession in the recognition scene of the second act (Eur. El. 579-581):

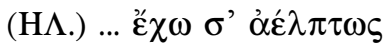

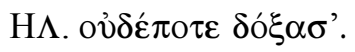

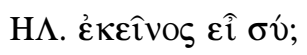

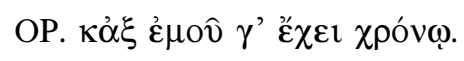

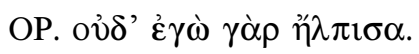

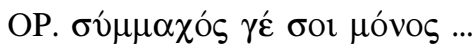

Sophocles has 29 verses split between two characters, 17 of them between Orestes and Electra, 4 between Electra and chorus, 4 between Electra and Clytaemnestra and 4 between Orestes and Aegisthus. While in Euripides' Electra all the split lines occur in dialogue verses, Sophocles uses this device four times also in lyrical parts (between Electra and the chorus). In Sophocles split verses are characteristic above all to the main characters, of the marginal personages Aegisthus is the only one who has splits; there are no such lines in the parts of Chrysothemis and the pedagogue.

In Sophocles there occurs also a verse with a double split: Soph. El. 1502

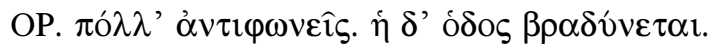

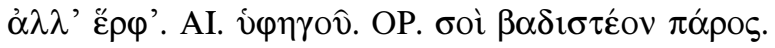


and even with the triple split: Soph. El. 845:

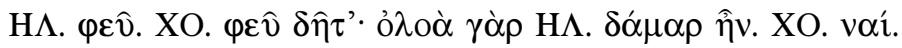

There are also two cases of an utterance consisting of the second half of a verse and the first half of the following verse (these are utterances of Orestes and Clytaemnestra), e.g., Soph. El. 1410-1411:

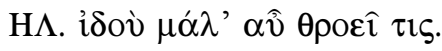

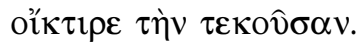

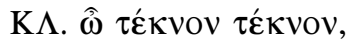

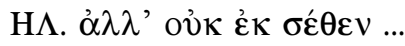

Speaking of the split verses in Elektra of Sophocles, it is important to notice that they all occur in the second half of the tragedy (starting from v. 831), contributing thus to the rising tension of the drama. The average length of utterances becomes shorter (before v. 831 it is 6.3, after that 2.3) and, therefore, the index of liveliness in the second half of the tragedy is considerably higher (before v. 831 it is 0.16 , i.e. comparable to the data of Libation Bearers of Aeschylus, but after that even 0.43).

\subsection{Metrical positions of splits}

Euripides has only a few character exchanges inside verses and the metrical position of them is rather standard: in three cases out of four they occur in the position of penthemimeral caesura (i.e. the main caesura of iambic trimeter), while Electra's utterance comprises positions ${ }^{4} A_{1}-A_{3}$ and that of Orestes $B_{3}-B_{6}$. The fourth case of split is found after the second A position, where again first comes Electra's utterance $\left(A_{1}-A_{2}\right)$, which is then followed by Orestes' utterance $\left(B_{2}-\right.$ $\mathrm{B}_{6}$ ). This is to say that character exchanges occur in positions where syntagmatic word-ends are statistically more frequent.

The division of verses with one split in Sophocles is displayed in Table 3. We see that most splits fall on the main caesuras (penthemimeral and hepthemimeral caesuras, i.e. the caesuras in the third and the fourth foot); there is only one case where it takes places on the verse foot boundary (after the utterance by Orestes).

4 ' $A$ ' stands for a weak and ' $B$ ' for a strong position in a verse foot; indices show the number of a feet. 
Table 3. Verse parts resulting from one split.

\begin{tabular}{|l|c|c|c|c|c|c|c|}
\hline & $\mathrm{A}_{1}-\mathrm{A}_{3}$ & $\mathrm{~A}_{1}-\mathrm{A}_{4}$ & $\mathrm{~B}_{3}-\mathrm{B}_{6}$ & $\mathrm{~B}_{4}-\mathrm{B}_{6}$ & $\mathrm{~B}_{2}-\mathrm{B}_{6}$ & $\mathrm{~A}_{1}-\mathrm{B}_{1}$ & $\mathrm{~L}$ \\
\hline Electra & 7 & 4 & 6 & 3 & 1 & & 4 \\
\hline Orestes & 5 & 1 & 11 & 3 & & 1 & \\
\hline Aegisthus & 4 & & & & & & \\
\hline Clytaemnestra & 2 & 1 & & 1 & & & \\
\hline Chorus & & & & & & & 4 \\
\hline
\end{tabular}

\section{Character analysis}

\subsection{Electra}

Electra's character is quite different in every analysed author. In Aischylos she is a weak and unsteady personage, who feels passionate hatred against her mother and who is ruled by her emotions rather than her reason (cf. also Cockburn 2002). Electra in Aeschylus has 169 verses altogether, $15.7 \%$ of the whole tragedy. Electra's utterances form $21.7 \%$ of the utterances in the whole tragedy (she has 44 utterances), and in this respect she is the third after Orestes and the chorus. The majority of her utterances are short $(81.8 \%)$, medium utterances compose $13.6 \%$ and long utterances $4.5 \%$. The greater part of utterances are one line long $(65.9 \%)$, the longest utterance consists of 29 lines.

Table 4. The metrical structure of the characters in Libation Bearers of Aeschylus (per cent).

\begin{tabular}{|l|c|c|c|}
\hline & Dialogue verses & Lyrical verses & Total amount \\
\hline Electra & 74.6 & 25.4 & 100.0 \\
\hline Pylades & 100.0 & 0.0 & 100.0 \\
\hline Orestes & 87.9 & 12.1 & 100.0 \\
\hline Servant A & 100.0 & 0.0 & 100.0 \\
\hline Clytaemnestra & 100.0 & 0.0 & 100.0 \\
\hline Servant B & 100.0 & 0.0 & 100.0 \\
\hline Chorus & 18.6 & 81.4 & 100.0 \\
\hline Nurse & 100.0 & 0.0 & 100.0 \\
\hline Aegisthus & 93.3 & 6.7 & 100.0 \\
\hline
\end{tabular}


Table 4 illustrates the metrical structure of the characters in Libation Bearers 5 .

It appears that Electra has a higher proportion of lyrical verses than the other characters (except, of course, the chorus). The length of the role is not decisive here, since Orestes, whose role is somewhat longer than that of Electra, has a significantly lower proportion of lyrical verses (in fact, the number of lyrical verses in their roles is almost equal: Electra has 43 of these, Orestes 41, but the amount of dialogue verses in Orestes' role is bigger).

Tables 5 and 6 show the occurrences of resolved verses (i.e. verses where a long syllable is replaced with two short ones) in different roles.

Table 5. Resolutions in Libation Bearers of Aeschylus.

\begin{tabular}{|l|c|c|c|c|}
\hline & $\begin{array}{c}1 \text { reso- } \\
\text { lution }\end{array}$ & $\begin{array}{c}2 \text { reso- } \\
\text { lutions }\end{array}$ & $\begin{array}{c}\text { Total amount } \\
\text { of resolutions }\end{array}$ & $\begin{array}{c}\text { Total amount } \\
\text { of verses }\end{array}$ \\
\hline Orestes & 17 & 0 & 17 & 338 \\
\hline Electra & 10 & 1 & 11 & 169 \\
\hline Chorus & 1 & 0 & 1 & 446 \\
\hline Servant A & 1 & 0 & 1 & 1 \\
\hline Clytaemnestra & 4 & 0 & 4 & 48 \\
\hline Nurse & 2 & 0 & 2 & 39 \\
\hline Servant B & 1 & 0 & 1 & 11 \\
\hline
\end{tabular}

Table 6. Resolutions in Libation Bearers of Aeschylus (per cent).

\begin{tabular}{|l|c|c|c|c|}
\hline & $\begin{array}{c}1 \text { reso- } \\
\text { lution }\end{array}$ & $\begin{array}{c}2 \text { reso- } \\
\text { lutions }\end{array}$ & $\begin{array}{c}\text { Total amount of } \\
\text { resolutions }\end{array}$ & $\begin{array}{c}\text { Total amount } \\
\text { of verses }\end{array}$ \\
\hline Orestes & 5.0 & 0.0 & 5.0 & 100.0 \\
\hline Electra & 5.9 & 0.6 & 6.5 & 100.0 \\
\hline Chorus & 0.2 & 0.0 & 0.2 & 100.0 \\
\hline Servant A & 100.0 & 0.0 & 100.0 & 100.0 \\
\hline Clytaemnestra & 8.3 & 0.0 & 8.3 & 100.0 \\
\hline Nurse & 5.1 & 0.0 & 5.1 & 100.0 \\
\hline Servant B & 9.1 & 0.0 & 9.1 & 100.0 \\
\hline
\end{tabular}

5 There is no special analysis of the metrical structure of lyrical parts in the present work, for this, see, e.g., Jebb 1924: 1xxii-xcii; Denniston 1998: 213-225; West 1990: 492-498. 
It appears that in comparison with the other characters Electra has quite a lot of resolutions (Orestes has numerically more of them, but his part is also more than twice as long than that of Electra). Electra is the only character who has a verse with the double resolution. The analysis of the positions of resolutions revealed that almost all the resolutions in Electra's part occur in positions $B_{1}(6)$ and $B_{3}(5)$, there is only one resolution in $\mathrm{B}_{4}$.

Electra of Sophocles is the central character of the tragedy; she is a

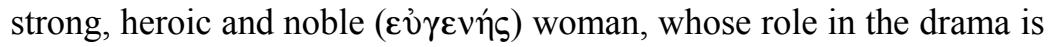
recurrent, but at the same time rather complicated (cf. also Winthrop 2002; Hazel 1999: 4; Winnington-Ingram 1980). Electra's part in Sophocles consists of 643 verses, i.e. $44.4 \%$ of the total amount of verses. She has 166 utterances $(40.8 \%)$, which is twice as much as the number of utterances by Orestes who is the second character in importance. Short utterances form $87.3 \%(0,25-5)$ of her part, medium utterances $7.8 \%$ and long utterances $4.8 \%$. There are fewer one line long utterances than in Aeschylus (47\%), but the longest utterance has as much as 69 lines. From the aspect of semantics such metrical repertoire adds special nuances to Electra's role, emphasizing her passion and intensity.

Table 7 illustrates the metrical structure of the characters in Electra of Sophocles.

Table 7. The metrical structure of the characters in Electra of Sophocles (per cent).

\begin{tabular}{|l|c|c|c|}
\hline & Dialogue verses & Lyrical verses & Total amount \\
\hline Electra & 72.4 & 27.6 & 100.0 \\
\hline Pedagogue & 100.0 & 0.0 & 100.0 \\
\hline Orestes & 87.9 & 12.1 & 100.0 \\
\hline Chrysothemis & 100.0 & 0.0 & 100.0 \\
\hline Clytaemnestra & 95.7 & 4.3 & 100.0 \\
\hline Aegisthus & 100.0 & 0.0 & 100.0 \\
\hline Chorus & 19.9 & 80.1 & 100.0 \\
\hline
\end{tabular}

Sophocles' Electra has also more lyrical verses than any other character (numerically, she exceeds even the part of chorus). Orestes shows almost the same data as in Aeschylus, but we should also 
remember, that Electra's role is the biggest in terms of both the total amount of verses as well as utterances. The occurrences of resolved verses are presented in Tables 8-9.

Table 8. Resolutions in Electra of Sophocles.

\begin{tabular}{|l|c|c|c|c|}
\hline & $\begin{array}{c}1 \text { reso- } \\
\text { lution }\end{array}$ & $\begin{array}{c}2 \text { reso- } \\
\text { lutions }\end{array}$ & $\begin{array}{c}\text { Total amount } \\
\text { of resolutions }\end{array}$ & $\begin{array}{c}\text { Total } \\
\text { amount of } \\
\text { verses }\end{array}$ \\
\hline Orestes & 9 & 0 & 9 & 160.6 \\
\hline Electra & 14 & 1 & 15 & 641 \\
\hline Chorus & 2 & 1 & 3 & 191 \\
\hline Pedagogue & 14 & 0 & 14 & 149 \\
\hline Clytaemnestra & 6 & 0 & 6 & 114 \\
\hline Chrysosthemis & 1 & 0 & 1 & 156 \\
\hline Aegisthus & 3 & 0 & 3 & 33.3 \\
\hline
\end{tabular}

Table 9. Resolutions in Electra of Sophocles (per cent).

\begin{tabular}{|l|c|c|c|c|}
\hline & $\begin{array}{c}1 \text { reso- } \\
\text { lution }\end{array}$ & $\begin{array}{c}2 \text { reso- } \\
\text { lutions }\end{array}$ & $\begin{array}{c}\text { Total amount of } \\
\text { resolutions }\end{array}$ & $\begin{array}{c}\text { Total } \\
\text { amount of } \\
\text { verses }\end{array}$ \\
\hline Orestes & 5.6 & 0.0 & 5.6 & 100.0 \\
\hline Electra & 2.2 & 0.2 & 2.3 & 100.0 \\
\hline Chorus & 1.0 & 0.5 & 1.6 & 100.0 \\
\hline Pedagogue & 9.4 & 0.0 & 9.4 & 100.0 \\
\hline Clytaemnestra & 5.3 & 0.0 & 5.3 & 100.0 \\
\hline Chrysosthemis & 0.6 & 0.0 & 0.6 & 100.0 \\
\hline Aegisthus & 9.0 & 0.0 & 9.0 & 100.0 \\
\hline
\end{tabular}

Considering both the facts that the occurrences of resolutions in Sophocles are somewhat more frequent and that Electra's part in Sophocles is almost four times as long as that in Aeschylus, we can say that in comparison with the latter, the verses of Electra in Sophocles are less varying and stricter (the proportion of resolved verses of Electra is $6.5 \%$ in Aeschylus' play and 2.3\% in Sophocles' play). It should be noticed that Sophocles also allows a double resolution to occur namely in Electra's part, which is still quite a rare 
occasion (besides Electra, such device is used only in the part of chorus). Sophocles, too, resolves in Electra's part mostly the position $B_{3}(8)$, positions $A_{1}, B_{1}, B_{2}$ and $B_{4}$ have two resolutions.

Euripides' Electra, on the contrary to the noble and tragic heroine of Sophocles, is more commonplace, ordinary, human (Tucker 1901: lvi); some researchers have even seen her as a neurotic, disturbed woman, embittered by her own sufferings as well as by the hatred against her mother, there have been also implications to her sexual frustration resulting from the unconsummated marriage (cf., e.g., Hazel 1999; Winnington-Ingram 1980: 231). Electra of Euripides utters 467 verses (i.e. $34.6 \%$ of the whole tragedy), which are divided into 136 utterances $(38.4 \%)$ - she has more utterances than any other personage in the tragedy (she is followed by Orestes with 103 utterances). Most of the utterances are short $(0.5-5)-88.2 \%$, medium utterances form $8.8 \%$, long ones $2.9 \%$. The majority of utterances in the part of Electra in Euripides consists of one-line long utterances $(70.6 \%)$, the longest speech comprises 56 lines.

Table 10 shows the metrical structure of characters in Electra of Euripides.

Table 10. The metrical structure of characters in Electra of Euripides (per cent).

\begin{tabular}{|l|c|c|c|}
\hline & Dialogue verses & Lyrical verses & Total amount \\
\hline Electra & 76.7 & 23.3 & 100.0 \\
\hline Peasant & 100.0 & 0.0 & 100.0 \\
\hline Orestes & 81.8 & 18.2 & 100.0 \\
\hline Old man & 100.0 & 0.0 & 100.0 \\
\hline Clytaemnestra & 97.3 & 2.7 & 100.0 \\
\hline Castor & 62.8 & 37.2 & 100.0 \\
\hline Chorus & 8.4 & 91.6 & 100.0 \\
\hline Messenger & 100.0 & 0.0 & 100.0 \\
\hline
\end{tabular}

While in the dramas by the other two authors the biggest proportion of lyrical verses belongs to Electra, in Euripides such verses are most characteristic of Castor, one of the dioscuri, of whose part almost $40 \%$ is lyrical. Nevertheless, Electra of Euripides is rather similar to the heroine of Aeschylus and Sophocles: she differs from them only 
slightly (we should not forget, however, that conceptually the roles of Electra in the three studied tragedies are rather different, thus, here as well, the relation to semantics is weak). In Euripides also Electra is followed by Orestes, although he has less dialogue verses than Orestes in Aeschylus or Sophocles.

Data of the resolved verses in Electra of Euripides are presented in the Tables 11-12.

Table 11. Resolutions in Electra of Euripides.

\begin{tabular}{|l|c|c|c|c|c|}
\hline & $\begin{array}{c}1 \text { reso- } \\
\text { lution }\end{array}$ & $\begin{array}{c}2 \text { reso- } \\
\text { lutions }\end{array}$ & $\begin{array}{c}3 \text { reso- } \\
\text { lutions }\end{array}$ & $\begin{array}{c}\text { Total } \\
\text { amount of } \\
\text { resolutions }\end{array}$ & $\begin{array}{c}\text { Total } \\
\text { amount of } \\
\text { verses }\end{array}$ \\
\hline Orestes & 25 & 1 & 0 & 26 & 225 \\
\hline Electra & 63 & 6 & 1 & 70 & 467 \\
\hline Chorus & 3 & 0 & 0 & 3 & 227 \\
\hline Peasant & 21 & 1 & 0 & 22 & 90 \\
\hline Clytaemnestra & 14 & 1 & 0 & 15 & 75 \\
\hline Old man & 17 & 1 & 0 & 18 & 88 \\
\hline Messenger & 15 & 4 & 0 & 19 & 91 \\
\hline Castor & 12 & 1 & 0 & 13 & 86 \\
\hline
\end{tabular}

Table 12. Resolutions in Electra of Euripides (per cent).

\begin{tabular}{|l|c|c|c|c|c|}
\hline & $\begin{array}{c}\text { 1 reso- } \\
\text { lution }\end{array}$ & $\begin{array}{c}\text { 2 reso- } \\
\text { lutions }\end{array}$ & $\begin{array}{c}\text { 3 reso- } \\
\text { lutions }\end{array}$ & $\begin{array}{c}\text { Total } \\
\text { amount of } \\
\text { resolutions }\end{array}$ & $\begin{array}{c}\text { Total } \\
\text { amount of } \\
\text { verses }\end{array}$ \\
\hline Orestes & 11.1 & 0.4 & 0.0 & 11.6 & 100.0 \\
\hline Electra & 13.5 & 1.3 & 0.2 & 15.0 & 100.0 \\
\hline Chorus & 1.3 & 0.0 & 0.0 & 1.3 & 100.0 \\
\hline Peasant & 23.3 & 1.1 & 0.0 & 24.4 & 100.0 \\
\hline Clytaemnestra & 18.7 & 1.3 & 0.0 & 20.0 & 100.0 \\
\hline Old man & 19.3 & 1.1 & 0.0 & 20.5 & 100.0 \\
\hline Messenger & 16.5 & 4.4 & 0.0 & 20.9 & 100.0 \\
\hline Castor & 14.0 & 1.2 & 0.0 & 15.1 & 100.0 \\
\hline
\end{tabular}

In comparison with the other authors the rhythmical structure of Euripides' tragedy is quite dissimilar (cf. also West 1982: 85). Probably 
the most conspicuous is the frequency of resolutions and the admittance of three resolutions per verse line (in this tragedy only once, in Electra's part). The proportion of resolved verses in the part of Electra is several times bigger than that in Aeschylus' drama: 15\%.

Like in the earlier authors, Electra of Euripides resolves mainly in the position $B_{3}(41)$, there are also quite many resolutions in $A_{1}(14$ times) and $B_{2}$ (10 times), in addition to that there are resolutions also in positions $\mathrm{B}_{4}(7), \mathrm{B}_{1}(5)$ and $\mathrm{A}_{3}(1)$.

\subsection{Orestes}

Orestes of Aeschylus is strong, resolved, an equal adversary to Clytaemnestra (Cockburn 2002). His choice is not simple, but he understands that leaving his father unavenged is worse than killing his mother (Jebb 1924: xxx). Nevertheless, he has a moment of inner struggles (v. 898), yet he dismisses them with the help of Pylades, who reminds him of Apollo's oracle. Orestes' part consists of 340 verses, which is $31.6 \%$ of the whole tragedy. As for the amount of utterances, Orestes holds the second place after the chorus: he has 62 speeches $(30.5 \%$ of the total amount of utterances). Most of his utterances are short $(74.2 \%)$, there are $17.7 \%$ medium utterances and $8.1 \%$ long ones. The proportion of one-line utterances is smaller than that of Electra (45.2\%), the longest utterance is 37 lines.

As it has already been said, with respect to the proportion of lyrical verses, Orestes of Aeschylus comes second after Electra (cf. also Table 4). There are also relatively many resolved verses in his part (5\%, cf. also Table 5). Most of the resolutions occur in positions $\mathrm{B}_{3}$ (6) and $\mathrm{A}_{1}(5)$, then $\mathrm{B}_{1}(3), \mathrm{B}_{4}(2)$ and $\mathrm{B}_{2}(1)$.

Orestes as portrayed by Sophocles is, in a way, a contradictory personage. On the one hand he is a determined and unhesitating character, but on the other hand he has been interpreted as a naïve, childish person, who is motivated not by the sense of justice, but by Apollo's orders and who accomplishes a certain maturity only at the end of the drama (cf., e.g., Winthrop 2002). Orestes' vengeance is the re-establishment of justice which evokes no moral hesitations (cf. also Goldhill 1992: 94). In comparison with Orestes of Aeschylus his part is much smaller: 160.6 verses, i.e. $11.1 \%$ of the tragedy, are divided into 76 utterances $(18.8 \%)$, which make him the second character after Electra. The absolute majority of Orestes' utterances are short (0.3-5): 
$97.4 \%$, there are very few medium and long utterances (i.e., both comprise just $1.3 \%$ of his part). There, too, the most preferred length is one line $(47.4 \%)$, the longest part consists of 54 verses.

The proportion of resolved verses in Orestes of Sophocles is slightly bigger than that of Aeschylus: $5.6 \%$, mainly, these occur in the position $\mathrm{B}_{3}(5)$, also in $\mathrm{B}_{2}(2), \mathrm{A}_{1}(1)$ and $\mathrm{B}_{1}(1)$.

Euripides takes from his Orestes the heroic aureola: Orestes is a weak man, who arouses sympathy in spectators, being only an instrument in god's hands, not acting upon his own free will. Electra's part in the revenge is bigger (Jebb 1924: lii). Orestes of Euripides has 103 utterances $(29.1 \%)$, all in all 225 verses, i.e. $16.7 \%$ of the whole tragedy. The occurrence of the short utterances is $93.2 \%$, that of the medium utterances is $4.9 \%$ and long utterances $1.9 \% .75 .7 \%$ of utterances are one-line long, the longest utterance is composed of 34 lines.

Considering a relatively high proportion of resolutions in Euripides, their occurrence in the part of Orestes is rather low: $11.6 \%$. The substantial part of them is found in the position $B_{3}(13)$, then in $B_{1}(4)$, $\mathrm{A}_{1}$ and $\mathrm{B}_{2}$ (3 in both), $\mathrm{B}_{4}(2), \mathrm{A}_{2}$ and $\mathrm{B}_{5}$ (1 in both).

\subsection{Clytaemnestra}

In the case of Clytaemnestra of Aeschylus we must take into consideration that her personage was created already in the first part of the trilogy (Agamemnon). Aeschylus portrays Clytaemnestra as a complicated and controversial character who, in a way, is the antiideal of motherhood and femininity (cf., e.g., Winnington-Ingram 1983: 84 or Winnington-Ingram: 102), yet, at the same time, a good mother who avenged her daughter's murder (Cockburn 2002). Her part is rather short: 48 verses $(4.5 \%)$, which are divided into 18 utterances $(8.9 \%)$. Therefore, Clytaemnestra comes in this respect fourth after Electra, Orestes and the chorus. There are no long utterances in her part; $83.3 \%$ are short utterances and $16.7 \%$ medium utterances. $72.2 \%$ of her part consists of one-line utterances, the longest utterance has 12 lines.

Seemingly, the rhythmics of Clytaemnestra's part is the most variable in the drama: resolved verses make up as much as $8.3 \%$ of her part. However, her role is short and the actual amount of resolutions is not big: there are three resolutions in the position $\mathrm{B}_{3}$ and one 
in $\mathrm{B}_{4}$. Metrically, it is significant that Clytaemnestra's part consists $100 \%$ of iambic trimeters.

Clytaemnestra as treated by Sophocles is, on the one hand, a cruel, ruthless, arrogant and overbearing woman, but she has a softer side as well: receiving a false message of Orestes' death, she feels genuine maternal grief (Jebb 1924: xliv, Winnington-Ingram 1980: 232), she also tries to justify her crime by saying that it was motivated by a wish to avenge her daughter. Clytaemnestra's role in Sophocles consists of 114 verses $(7.9 \%)$. The total percentage of her utterances is $5.9 \%$, of which $87.5 \%$ are short, $4.2 \%$ of medium length and $8.3 \%$ long. Only the pedagogue and Aegisthus have less utterances than Clytaemnestra. Surprisingly, the most preferred type of utterance in Clytaemnestra's part is a two-lined utterance. The longest speech has 36 lines.

While the part of Clytaemnestra in Aeschylus consists only of dialogue verses, then in Sophocles Clytaemnestra utters also lyrical verses $(4.3 \%)$. As for the rhythmics, it is interesting to note that most of the variations occur in the position $\mathrm{A}_{4}(3)$, which is a rather unusual place for resolving. There are two resolutions in the position $\mathrm{B}_{3}$ and one in $\mathrm{B}_{1}$.

Similarly to other characters in Euripides' Electra, also his Clytaemnestra is more human and lifelike than the one portrayed by Sophocles or Aeschylus. Aegisthus is more responsible for the crime, Clytaemnestra is weaker and less consistent (Tucker 1901: 1xi), but therefore less repulsive than that of Sophocles (Denniston 1998: xxx). As in the other authors, the role of Clytaemnestra in Euripides is quite short: 75 verses, i.e. $5.6 \%$, and composed of 16 utterances $(4.5 \%$; only the messenger, Castor and the peasant have less than that). $75 \%$ of them are short utterances, $18.8 \%$ medium and $4.2 \%$ long ones. The most frequent are the one-line long utterances $(68.8 \%)$, the longest one consists of 40 lines.

Although the substantial part of Clytaemnestra's role is in iambic trimeters, she also has two lyrical verses. Considering the average rate of resolutions in Euripides, the variability in her part is quite high $(20 \%)$, there are seven resolutions in $B_{3}$, four in $A_{1}$, two in $B_{2}$ and $A_{4}$ and one in $\mathrm{A}_{3}$. 


\subsection{The chorus}

The chorus of Aeschylus is made up of fifteen Trojan captives. Their attitude is quite clear: they favour Electra, being her counsellors and supporters. The chorus also emphasises the will of gods and the inevitable reestablishment of justice (Jebb 1924: xxxi). The chorus has the biggest part in the tragedy: 447 verses, i.e. $41.6 \%$, it also has the biggest number of utterances: 63 (31\%). Furthermore, the longest utterance of this tragedy belongs to the chorus. However, the most preferred are the short utterances $(76.2 \%)$, of which $36.5 \%$ are oneline verses, $17.5 \%$ of medium length and $6.3 \%$ long.

The chorus of Sophocles consists of fifteen free women of Mycenae. They are also sympathetic to Electra, but the background of such attitude is different: the chorus is characterized by patriotism and hostility against usurpers. The restoration of the continuity of power is in the interests of the chorus and therefore they support Agamemnon's son (Jebb 1924: xxxi). The part of the chorus consists of 191 verses, i.e. $13.2 \%$. As for the number of utterances, then here the chorus is the third (53 speeches; although Crysothemis has the equal amount of utterances, the total number of verses in her part is smaller), $83 \%$ of the utterances are short, $13.2 \%$ of medium length and $3.8 \%$ long. The one-line utterances are the most frequent (28.3\%), the longest utterance consists of 36 lines.

Euripides forms his chorus of the friendly Argive countrywomen. The part of chorus is somewhat longer than that of Electra by Sophocles, but still almost two times shorter as compared with the tragedy of Aeschylus: 227 verses, i.e. 16.8\%. At the same time the number of utterances is the smallest in all the analysed tragedies: 30 utterances $(8.5 \%) .66 .7 \%$ of the utterances are short, $26.7 \%$ medium and $6.7 \%$ long.

It is obvious that in all the studied tragedies the substantial part of the chorus consists of lyrical verses. Still the chorus sometimes intervenes in the dialogue parts: the data of Aeschylus and Sophocles are here almost the same - a little less than $20 \%$ of the verses, but in Euripides considerably less - 8.4\%. Naturally, the chorus has the fewest amount of resolutions: only once in Aeschylus $\left(\mathrm{B}_{3}\right)$, four times in Sophocles $\left(\mathrm{B}_{1}, \mathrm{~B}_{2}, \mathrm{~B}_{3}\right.$ and $\left.\mathrm{B}_{5}\right)$ and three times in Euripides (two of them in $\mathrm{B}_{3}$ and one in $\mathrm{B}_{2}$ ). 


\subsection{Minor characters}

Less important characters in Aeschylus are the following:

(a) Pylades, Orestes' friend, who has one three-lined utterance $(0.3 \%$ of all the verses);

(b) a servant, who opens the door to Orestes and Pylades and thereby pronounces one utterance, comprising one line $(0.1 \%)$;

(c) a servant of Aegisthus, who has two utterances (one- and ten-lined; $1 \%)$;

(d) Aegisthus, who also has a very short role $(1.4 \%$; i.e. it consists of only 15 verses and three utterances, of which one is only a gasp of

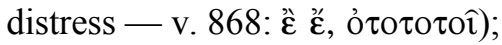

(e) the nurse, whose role in the tragedy is to deliver a message to Aegisthus. The nurse has seven utterances and 39 verses altogether (3.6\% of the whole tragedy). The most frequent are one-line utterances $(71.4 \%)$, the longest utterance in her part has 32 lines.

As for the metrics, it is noteworthy that, as a rule, the minor characters speak in iambic trimeters, the only exception being Aegisthus, in whose part we also find a lyrical verse (the above-mentioned gasp of sorrow). Resolutions occur only in the parts of both servants (they both have one resolution in the position $\mathrm{B}_{3}$ ) and the nurse (twice in $\left.\mathrm{B}_{3}\right)$.

Sophocles has only three minor characters:

(a) the pedagogue, whose role is relatively short, yet, at the same time includes the longest utterance of the given tragedy, consisting of 84 lines. The pedagogue of Sophocles has 149 verses $(10.3 \%)$, i.e. 18 utterances altogether $(4.4 \%)$, of which the most preferred are one-line utterances $(44.4 \%)$;

(b) Electra's lovely, but weaker sister Chrysothemis provides contrast with the heroic nature of the protagonist (Jebb 1924: xlii; Winnington-Ingram 1980: 239). Her part is not small at all: she speaks all in all 53 mainly one-line $(67.9 \%)$ utterances, i.e. 156 verses $(10.8 \%)$. The longest utterance of Chrysothemis has 28 lines;

(c) the part of Aegisthus is in Sophocles also very small (33.3 verses, i.e. $2.3 \%$ of the whole tragedy). Aegisthus has 17 utterances $(4.2 \%)$, of which $29.4 \%$ are one-line long. He has no long speeches, the longest ones in his part are two six-line utterances. 
As in Aeschylus, the minor characters of Sophocles speak mainly in iambic trimeters. Rhythmically, the most important part is that of the pedagogue, who has the biggest proportion of resolved verses $(9.4 \%)$ and unusual locations of resolutions (six times in $\mathrm{A}_{1}$, three times in $\mathrm{B}_{1}$ and $\mathrm{A}_{4}$ and only two times in $\mathrm{B}_{3}$ ) - he is the only character whose most preferable location of variations is the first foot. Chrysothemis and Aegisthus have both one resolution (considering the latter's short part in the tragedy, it is not surprising, however, in the case of Chrysothemis one would expect more).

Euripides has four minor characters:

(a) the husband of Electra, who is called simply the peasant ( $\alpha$ vovpyós) and whose monologue of 53 lines opens the tragedy. All in all, he utters 90 verses $(6.7 \%)$ or 11 utterances $(3.1 \%)$, of which the one-line utterances are the most frequent $(36.4 \%)$;

(b) a former servant of Agamemnon, who is called the old man in the drama - his part is quite lively: 88 verses $(6.5 \%)$, which make up as much as 45 speeches (12.7\%). Thus, the old man has a rather big proportion of one-line utterances $(82.2 \%)$, the longest one has 16 lines;

(c) Castor $^{6}$, who appears ex machina and whose tacit companion is his twin-brother Pollyx, has altogether 86 verses $(6.4 \%)$ or 9 utterances $(2.5 \%)$, the most common type of which has two lines $(33.3 \%)$ and the longest consists of 54 lines;

(d) the messenger, who is a servant of Orestes and who brings the message of the death of Aegisthus, utters 91 verses (6.7\%) in only four speeches $(1.1 \%)$, of which two are one-line, one four-line and one 85-line long (being also the longest utterance in this tragedy).

The minor characters also in Euripides utter generally dialogue verses; the rate of resolutions in their parts is rather high as well, thus, e.g., in the peasant's case it is as much as $24.4 \%$, in the other characters except Castor it also exceeds $20 \%$ (there are only $15 \%$ of them in Castor's part and in this respect he is equal to the protagonist; this could also be the argument for excluding Castor's part from the original version; in addition to that, it is not in correspondence with the general metrical data of the tragedy, cf. Table 8). Minor personages prefer to resolve the first foot (the only exception here is

$6 \quad$ T. G. Tucker is convinced that the part of dioscuroi does not belong to the original version, but is a later supplement (cf. also Tucker 1901: xxxii). 
the messenger; in the case of the main characters the primary location of resolution is the third foot).

\section{Conclusion}

Although the material of the present research is not sufficient for the more general conclusions concerning the rhythm of characters, comprising, e.g. their gender, social status, positive or negative traits of character, some regularities were found after all. Thus, certain differences can be observed in the metrics and rhythmics of the main and minor characters.

These tendencies become most obvious when we compare Electra with minor characters. Namely, Electra of all the analysed tragedies has several features in common. First, she has always the biggest proportion of lyrical parts (in Euripides she is exceeded by Castor, but he is most probably a later supplement). As for the rhythmics, Electra has more unstandard settlements, e.g., she is the only character in Aeschylus and Sophocles who has verses with a double resolution, while in Euripides, whose Electra is the most resolved character whatsoever (if not to consider Castor), even a triple resolution can be found. Here it is also important to notice the indexical relationship between the rhythm and semantics: the more commonplace and less typical of tragedy the character is, the closer is its rhythmics to that of comedy. Electra has also more verses with splits than any other character. The index of liveliness of Electra is almost the same in all the authors (despite that, proportionally, it is one of the highest in Aeschylus, but quite average in Sophocles and Euripides).

Although the same tendencies in Orestes are more schematical, his metrics and rhythmics are rather similar to those of Electra. Thus, in respect of the proportion of lyrical verses, he always comes second after Electra; he also has quite many split verses.

At the same time, the parts of minor characters are usually made up entirely of iambic trimeters. The rhythmical variety of minor personages is higher than average, but there are no splits in their parts (except for Aegisthus). However, there are characters with unstandard rhythm, e.g., the pedagogue in Sophocles or Chrysothemis, who is a contrast to Electra by her nature as well as her rhythmics: the proportion of resolutions is almost four times smaller than that of Electra. The contrast with other minor characters is even bigger. 
Clytaemnestra is both rhythmically and metrically an intermediate character: in Aeschylus her part consists entirely of iambic trimeters, but in Sophocles and Euripides she pronounces a couple of lyrical verses as well. There are also some splits in her verses which usually do not occur in minor persons.

\section{References}

Cockburn, Cloe Frances 2002. SparkNote on The Libation Bearers. $<\mathrm{http} / / /$ www.sparknotes.com/drama/libationbearers/>

Denniston, John Dewar (ed.) 1998. Euripides Electra: edited with introduction and commentary by J. D. Denniston. Oxford: Clarendon Press.

Easterling, Patricia Elizabeth 1983. Character in Sophocles. In: Segal, Erich (ed.), Greek Tragedy. Modern Essays in Criticism. New York: Harper and Row, $183-145$.

Gasparov 1969 = Гаспаров, Михаил Леонович 1969. Работы Б. И. Ярхо по теории литературы. Труды по знаковым системам [Sign Systems Studies] 4: 504-514.

Goldhill, Simon 1992. Aeschylus: The Oresteia. Cambridge: Cambridge University Press.

Hazel, Ruth 1999. Electra: A fragmented woman. In: Theatre: Ancient and Modern (The January Conference 1999).

$<$ http://www.open.ac.uk/Arts/CC99/hazel.htm>

Jebb, Richard Claverhouse 1924. Sophocles: the Plays and Fragments. Part VI. The Electra. Cambridge: At the University Press.

Kells, J. H. (ed.) 1973. Sophocles. Electra. Cambridge: Cambridge University Press.

Lill, Anne 1988. Tragöödia contra komöödia. Vikerkaar 6: 57-60.

— 1994. Kuidas lõpevad tragöödiad? Akadeemia 2: 227-224.

Lloyd-Jones, Hugh; Wilson, Nigel Guy (eds.) 1990. Sophoclis fabulae. Oxford: Clarendon Press.

Stanford, William Bedell 1983. Greek Tragedy and the Emotions: An Introductory Study. London: Routledge \& Kegan Paul.

Taplin, Oliver 1983. Emotion and meaning in Greek Tragedy. In: Segal, Erich (ed.), Greek Tragedy. Modern Essays in Criticism. New York: Harper and Row, 1-12.

Tarlinskaja, Marina 1987. Shakespeare's verse: Iambic Pentameter and the Poet's idiosyncrasies. New York: Peter Lang.

Tucker, Thomas George 1901. The Choephori of Aeschylus. Cambridge: Cambridge University Press.

Way, Arthur S. 1966. Euripides with an English translation by Arthur S. Way. Vol. II. London: W. Heinemann.

West, Martin Litchfield 1982. Greek Metre. Oxford: Clarendon Press. 
- (ed.) 1990. Aeschyli tragoediae cum incerti poetae Prometheo. Stuttgart: Teubner.

Winnington-Ingram, Reginald Pepys 1980. Sophocles: An Interpretation. Cambridge: Cambridge University Press.

- 1983. Clytemnestra and the vote of Athena. In: Segal, Erich (ed.), Greek Tragedy. Modern Essays in Criticism. New York: Harper and Row, 84-103.

Winthrop, Elizabeth Hartley 2002. SparkNote on Electra.

$<\mathrm{http}: / /$ www.sparknotes.com/drama/electra/>

Zeitlin, Froma I. 1978. Dynamics of misogyny in the Oresteia. Arethusa 2: 149-181.

\section{О семантике ритма: формальные особенности в речах персонажей Орестеи}

Целью работы является анализ формальных особенностей речей персонажей Орестеи у Эсхила, Софокла и Еврипида. Сравниваются речи главных действующих лиц с репликами второстепенных персонажей; учитывается динамика и вариативность ритма, количество реплик, их длина, а также удельный вес речевого стиха в метрическом репертуаре персонажа.

Выяснилось, что показатели по Эсхилу и Софоклу оказываются близкими как с точки зрения общей динамики ритма («живость» ритма по Б. И. Ярхо; этим термином пользуются также М. Л. Гаспаров и М. Тарлинская), так и по динамике ритма у отдельных персонажей. Существенные различия обнаруживаются в речах главных и второстепенных действующих лиц. Особое место во всех трех трагедиях занимают монологи и реплики Электры, причем это касается как их метрических, так и ритмических параметров. Так, во всех трех трагедиях Электра чаще других персонажей использует лирические метры; что касается ритмики, то реплики Электры харатеризуются нестандартными формами: так в целом в ямбическом триметре избегаются стихи, содержащие более одной резолюции (двусложная реализация односложной позиции), в то время как в речах Электры у Эсхила и Софокла встречаются стихи с двумя резолюциями, а у Еврипида - с тремя. Начала и концы реплик Электры часто не совпадают с границами стиха. Речи Ореста демонстрируют те же тенденции, однако в менее выраженной форме. Реплики второстепенных персонажей не содержат лирических форм, их ритмика лишена индивидуальных особенностей, хотя в целом характеризуется более высокой по сравнению с основными персонажами вариативностью. Начала и концы реплик совпадают с границами стиха. 


\section{Rütmisemantikast: formaalsed erinevused karakterite vahel tragöödia Oresteia erinevates versioonides}

Töö eesmärgiks on analüüsida Oresteia karakterite formaalseid omadusi Aischylose, Sophoklese ja Euripidese käsitluses. Võrreldakse pea- ja kõrvaltegelasi, milleks võetakse arvesse tegelaste kõnede rütmilist elavust ja variatiivsust, repliikide arvu ja pikkust, samuti kõnelemisvärsside osakaalu vastava tegelaskuju meetrilises repertuaaris.

Analüüsist selgus, et Sophoklese ja Euripidese näitajad on üksteisele tunduvalt lähedasemad nii üldise "elavuse" poolest kui ka karakterite kõnede "elavuse" poolest. Kindlad erinevused ilmnesid pea- ja kõrvaltegelaste repliikide meetrikas ja rütmikas. Kõige selgemini tulevad need tendentsid välja Elektra ja ebaolulisemate tegelaste võrdlemisel. Nimelt on kõigis kolmes tragöödias Elektral mitmeid ühiseid jooni. Nii on temal alati kõige enam lüürilisi osi. Mis puudutab rütmikat, siis on Elektra värssides suhteliselt rohkem ebastandardseid lahendusi, nt on ta ainus tegelane Aischylosel ja Sophoklesel, kelle jambilistes trimeetrites tuleb ette kahekordset resolutsiooni, samas kui Euripidesel, kelle Elektra on üldse kõige enam resolveerunud tegelane (kui Kastorit mitte arvestada), võib tema osast leida koguni kolmekordse resolutsiooniga värsi. Samuti on Elektra tekstis kõikidest tegelastest kõige enam jagunemisi. Elektra "elavus" on kõikidel autoritel peaaegu võrdne (kuigi proportsionaalselt on see Aischylosel üks kõrgemaid, Sophoklesel ja Euripidesel keskmine).

Orestesel on samad tendentsid küll skemaatilisemad, kuid siiski on tema osade meetrika ja rütmika suhteliselt sarnane Elektra omale. Nii on ta lüüriliste värsside osakaalult alati teisel kohal Elektra järel, samuti on tal küllaltki palju jagunenud värsse.

Samal ajal koosnevad kõrvaltegelaste osad reeglina täielikult jambilistest trimeetritest. Vähemtähtsate tegelaskujude repliikide rütmiline variatiivsus on keskmisest kõrgem, kuid jagunemisi nende osades üldiselt ei leidu (erandiks on Aigisthos). Samas eristub teiste seast ebastandardse rütmiga tegelasi, nt Sophoklese Chrysothemis, kes kontrasteerub Elektraga nii loomuomaduste poolest kui ka oma rütmikalt: tema tekstis on resolutsioonide osakaal ligi neli korda väiksem kui Elektral. Kontrast teiste kõrvaltegelastega on veelgi suurem.

Klytaimnestra roll on rütmiliselt ja meetriliselt vahepealne: Aischylosel koosneb tema osa küll sajaprotsendiliselt dialoogivärsidest, kuid Sophoklesel ja Euripidesel toob ta kuuldavale ka üksikuid lüürilisi värsse. Samuti on tema osas ka mõned värsiridade jagunemised, mida kõrvaltegelastel üldiselt ei esine. 